\title{
ECONOMIC CONSEQUENCES AND VARIABLES INFLUENCING THE UPTAKE OF MOBILE FINANCIAL SERVICE IN UNBANKING POPULATION LIKE PAKISTAN
}

\author{
Zara Younus \\ MBA in Finance \\ Karachi University Business School \\ University of Karachi, Pakistan \\ E-mail: zara44younus@gmail.com \\ Dr. Sohaib Uz Zaman \\ Assistant Professor \\ Karachi University Business School \\ University of Karachi, Pakistan \\ E-mail: sohaibuzzaman@uok.edu.pk
}

\begin{abstract}
The growth of digital mobile devices enables the world to integrate and enables the masses to access and use services with optimism, speed and efficiency. These developments are on the rise in Pakistan. Market opportunities for digital financial services in Pakistan are projected to exceed \$36 billion by 2025, which will increase GDP by 7\%, create four million new jobs and generate \$263 billion in new deposits. This power can only be achieved through a robust and efficient DFS environment. Although Pakistan has a DFS environment, it is unfortunate that so far no research has been done to determine and analyze the economic impact of mobile banking services as well as factors affecting their use in developing countries like Pakistan, to this end, the methodology part will be divided into two parts: the first part will focus on the secondary data to analyze and determine the impact of mobile banking activity on GDP, employment, government taxes for support to reduce non-banking figures in Pakistan. The second part will focus on the primary data that will be used to investigate the influencing variables on the usage of mobile banking services. A self-administered questionnaire has been developed with 250 respondents, which will be distributed to mobile money users to get their ideas on mobile banking services. Its results will be evaluated using the Pearson correlation and multiple regressions. Affective factors are assessed under five factors: risk, perceived trust, costeffectiveness, accessibility and reliability using biometric analysis method in mobile banking. The study revealed that mobile financial services had positive impact on the economic indicators whereas factors like perceived trust, convenience and perceived risk had a significant influence on the adoption of mobile banking services but perceived cost and reliability were said to have insignificant influence on its adoption.
\end{abstract}

Keywords: Mobile Financial Services, Adoption, Economic Impact, Pakistan. 


\section{INTRODUCTION}

Individuals in need of capital may be unable to receive it due to a lack of access to financial services (Johnston \& Murdoch, 2008). More inclusive financial institutions can help the poor smooth their cash flows and safeguard them from economic vulnerability due to disability, accidents, theft, and unemployment. It may enable people to save and borrow, acquire assets, and make investments to change their lives (World Bank, 2012)".It can also help individuals improve their credit risk profiles, lowering the rates they have to pay for financial services, reducing personal stress, and providing access to lower-cost lending sources (Caskey, 2002)". "As a result, increasing access to financial services is crucial for development since it can boost economic growth and minimise wealth gaps. However, more than half of the world's population is still unbanked, which means they lack access to official financial institutions for saving and borrowing (Chala et al., 2009)". This was corroborated by a 2012 World Bank study, which discovered that just around half of the world's adult population (51\%) held accounts with a formal financial institution. Lower rates are found in middle-income (43\%) and low-income (23\%) countries (World Bank, 2012). Because of the rising use of mobile phones in developing countries, there has been a lot of interest in using mobile phones to reach the unbanked, particularly through the implementation of mobile phone-based financial services. . For example, it was stated in 2009 that 1 billion people lacked access to banks but did have access to mobile phones, with this figure predicted to climb to 1.7 billion by 2012 (Picken, 2009; Islam \& Salma, 2016). In recent years, there has been a lot of investment in mobile phone-based financial services technologies, as well as debate about the potential support for the poor and financially excluded (Porteous, 2006; Porteous \& Wishart, 2006; Vodafone, 2007; Bengens \& Soderberg, 2008). One of the expected benefits of using mobile financial services is the ability to send money over vast distances, particularly little amounts of money, at a lesser cost than other options available to the poor. Furthermore, it was thought that by providing financial services to the financially excluded via mobile phone networks, the poor would benefit from higher savings rates, higher income, and greater financial stress, among other things (Donner \& Tellez, 2008). This initiative was intended to expand access to formal credit while lowering the cost of providing them. It was also intended to improve payment system efficiency and reduce dependency on cash as a transactional medium (Porteus, 2006).

Pakistan's financial inclusiveness rate has recently reached $15 \%$. This means that currently, 85 percent of adults in Pakistan lack access to formal financial services. Among the remaining $15 \%, 5 \%$ are fully banked, which means they have access to a full range of financial services (including savings, insurance, and credit), and 10\% are economically inactive, which means they have just minimal access to financial services such as a savings account. Furthermore, even among the financially involved, critical services such as insurance and credit are underutilised, and MFS is almost non-existent. Financial inclusion, or the supply of low-cost financial services to a community, has been connected to a country's fulfilment of crucial economic and social goals. The provision of financial services attracts credit to the banking system, resulting in greater GDP. It encourages entrepreneurship by enhancing domestic capital formation. It also enhances the depth of a country's private sector, which leads to the creation of new jobs. These financial innovations diminish a country's total income disparity, increase income growth among the poorest quintile of the population, and accelerate poverty reduction.

Overall, the focus of this study will be on the economic benefits of mobile financial services, as well as the numerous factors that influence their utilization. Previous research has found a correlation between mobile banking usage and trustworthiness (Bhattacherjee, 2002). 
Lee (2009) found a strong relationship between mobile banking usage and Perceived Risks but no link between mobile banking usage and Security Risk. Along with these factors, (reliability) is expected to have a significant impact on how individuals use mobile financial services. A consumer must be confident that the system is reliable, that it protects their security, privacy, and data integrity, and that it provides a secure authentication method for mobile banking. As a result, this study will concentrate on the potential use of detection authentication to alleviate security issues while boosting the dependability and trustworthiness of mobile financial services for clients.

\section{Mobile Financial Services and Economic Growth}

\section{LITERATURE REVIEW}

Absence of capital, obligation assortment, liquidity, income execution, and low deals are the critical part of pecuniary (financial) limitations for private companies in non-industrial nations (Bngens \& Söderberg, 2011a). Chale and Mbamba (2015) concurred with Bngens and Söderberg (2011b) that mobile money improves small companies in Tanzania in an assortment of ways, including deals exchanges, stock buys, installment receipts, products and service installment, all of which bring about worked on economic execution. Andrianaivo and Kpodar (2012) found that in nations where mobile money has been sent, there is a positive connection between financial inclusion (as characterized by advance records per individual) and economic growth. In this manner it forms the following hypothesis:

\section{$H_{1}:$ Mobile financial services would have a significant and favorable impact on the country's economic growth}

\section{Mobile Financial Services and Factors Influencing Its Adoption}

Technology acceptance model have been truly examined and endorsed, and they are the most consistently used models for depicting how clients recognize new advancement (Venkatesh \& Davis, 2000; Omwansa et al., 2012; Masinge, 2010). These examinations utilized the original TAM components along with different variables like risk, trust, and cost of mobile monetary services. From literature review and for the purpose of this study, the study framework comprises of the elements that are affecting the reception (acceptance) of mobile banking services dependent on TAM approach as explanatory variable and reception of mobile monetary services as a predicted variable.

\section{Perceived Trust}

According to Dass and Pal (2011a), trust is a mental assumption that a believed part won't act sharply. Thus, when the client's confidence in the services provider rises, so it will build their eagerness to take part in versatile mobile financial transactions (Masinge, 2010). As indicated by Bengens and Söderberg (2008), a financial framework and its entertainers should be trusted, and they should chip away at rules that cultivate customer trust. Dass and Pal (2011b) found that in their investigation on rural unbanked adoption of mobile financial services, villagers preferred channels that could be trusted to conduct monetary transaction. As per considers, trustworthiness impacts the uptake of mobile banking services (Masinge, 2010; Amin, Baba, \& Mohammed, 2007; Horne \& Nickerson, 2013; Chitungo \& Munongo, 2013; Lule, 2008). 
$\mathrm{H}_{2}$ : Perceived trustworthiness in mobile financial services will have a beneficial impact on mobile financial service adoption

\section{Convenience}

Convenience is connected to the yield that comes from utilizing innovation (Amin et al., 2007). As indicated by Davis (1989), convenience is how much an individual thinks that utilizing a specific strategy will work on their exhibition. Various examinations have shown that perceived usefulness essentially affects the acknowledgment of mobile banking services (Aboelmaged in Gebba, 2013; Chitungo \& Munongo, 2013; Davis, 1989; Li, 2010; Sayid et al., 2012). Chitungo and Munongo (2013) in their review on the acknowledgment of mobile banking in Zimbabwe tracked down that ease of use decidedly affects the acknowledgment of mobile money services. Based on these studies the following hypothesis is proposed:

\section{H3: Convenience will have a beneficial impact on mobile banking service adoption}

\section{Perceived Risk}

Perceived risk addresses vulnerability, a forthcoming misfortune, or a security break that could bring about a financial misfortune (Chitungo \& Munongo, 2013; Lee, 2009). Monetary danger, security or protection hazard, social danger, time hazard, and execution hazard are for the most part instances of perceived risk (Lee, 2009). It is contended that the utilization of mobile financial services raises worries about monetary misfortunes, secret word security, network issues, hacking, and individual data misfortune. Therefore, it is said that perceived risk adversely affects mobile financial take-up.

\section{H4: Perceived risk will have a detrimental effect on mobile financial service adoption}

\section{Perceived Cost}

How much an individual accepts that utilizing mobile financial will cost cash is portrayed as cost (Chitungo \& Munongo, 2013). The expense might incorporate transactional costs, for example, service charges, mobile communication charges (like SMS or information), and cell phone costs (Chitungo \& Munongo, 2013). Dass \& Pal (2011a) found that monetary expense unfavorably affects the take-up of digital financial services. Moreover, cost contemplations might deter people from accepting mobile banking services in case they are restrictively costly, yet in case they are sensible, it tends to be an inspiration for quicker reception (Tobbin \& Kuwornu, 2011). In light of the above literature review, the accompanying hypothesis is proposed as:

\section{H5: $_{5}$ The perceived cost of mobile financial services will have a major negative impact on the adoption of mobile financial services}

\section{Reliability}

Reliability can likewise be considered as a predictor variable in the reception and utilization of digital banking services that can be included in TAM system since client acknowledgment is the super basic part in the reception of innovation like mobile money services without which any innovation can be outdated so for this reason solid and secure technique can be consider like bio metric instrument for accomplishing the client trust and acknowledgment in online payments through cell phone. Buckley and Nurse (2019) appear to demonstrate that fingerprint scanning is 
a widely used authentication mechanism. Finally, a 2015 South Korean study found that consumers are more inclined to utilise methods that are less secure but easier to use, such as fingerprint scanning. Finally, arguably the most concerning finding from their survey was that $83 \%$ of respondents believed biometric authentication methods are equally secure as passwords.

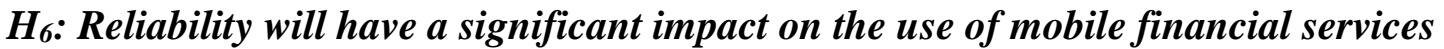

\section{Research Problem}

This study focuses on the economic impact of mobile financial services and the factors that influence their use in developing countries such as Pakistan, where the majority of the population does not use mobile internet or have access to formal financial services, putting them at risk of missing out the economic benefits of digital transformation. Gender, regional, economic, and literacy barriers all contribute to the exclusion gap. In Pakistan, for example, women are 37\% less likely than men to own a cell phone. Addressing the issue of service access and consumption is critical to optimising the impact of mobile-enabled digital transformation in Pakistan. Thus it addresses the following questions to be answered:

Question 1: Does mobile financial service has positive effect on country's economic growth? Question 2: What factors will influence its usage?

\section{Research Gap}

It is obvious that a vision of a technologically advanced financial inclusive ecosystem cannot be realised without the deployment of technologically innovative financial systems and solutions that provide unrestricted access to financial services to all citizens in the country. The idea is to leverage mobile financial services to create markets so inclusive that even tiny businesses in Pakistan, such as women who prepare fruit relishes in rural areas, can sell their products online across Pakistan and collect revenue digitally in their mobile wallets. Though Pakistan has a nascent and transformational role in the MFS ecosystem, the economic ramifications and factors that impact its use have been understudied thus far. As a result, it is deemed necessary to fill the gap by researching the connectivity of mobile financial services with the implications of economic factors and factors such as (perceived risk, trust, convenience, perceived cost, and reliability) that affect its usage when widely adopted in lower-middle income countries such as Pakistan.

\section{Significance of the Study}

The importance of this study is that mobile banking is not intended to replace the banking system today; rather, they aim to expand it and create more employment opportunities for many. Communication companies have a clear advantage in providing customers who have difficulty accessing traditional mobile banking services. The carrier (mobile operator) has a pre-existing relationship with customers who have purchased the required mobile phone, and it is a wellknown brand and trusted with a large secure server. With its vast experience serving many customers and answering their needs, the user is also able to focus on long tail customers. Traditional financial institutions often focus on people with large finances, high profits, and long stays. 


\section{RESEARCH METHODOLOGY}

As mentioned before, Pakistan has gained a dynamic role in mobile money services, but the economic implications and factors influencing the usage of mobile money services have yet to be thoroughly investigated. To solve this diagnostic problem, this study will focus on primary and secondary data. The secondary data will describe a graphical representation of the impact of MFS (mobile financial services) on the economic benefits on which first alternative hypothesis is based upon as its reference is given in the literature review. To test the remaining five hypothesis, primary data (questionnaire) will be used to study TAM (technology acceptance process) such as risk assumptions, trust assumptions, perceived cost, reliability, accessibility which will affect the use of mobile money services.

\section{Theoretical Structure}

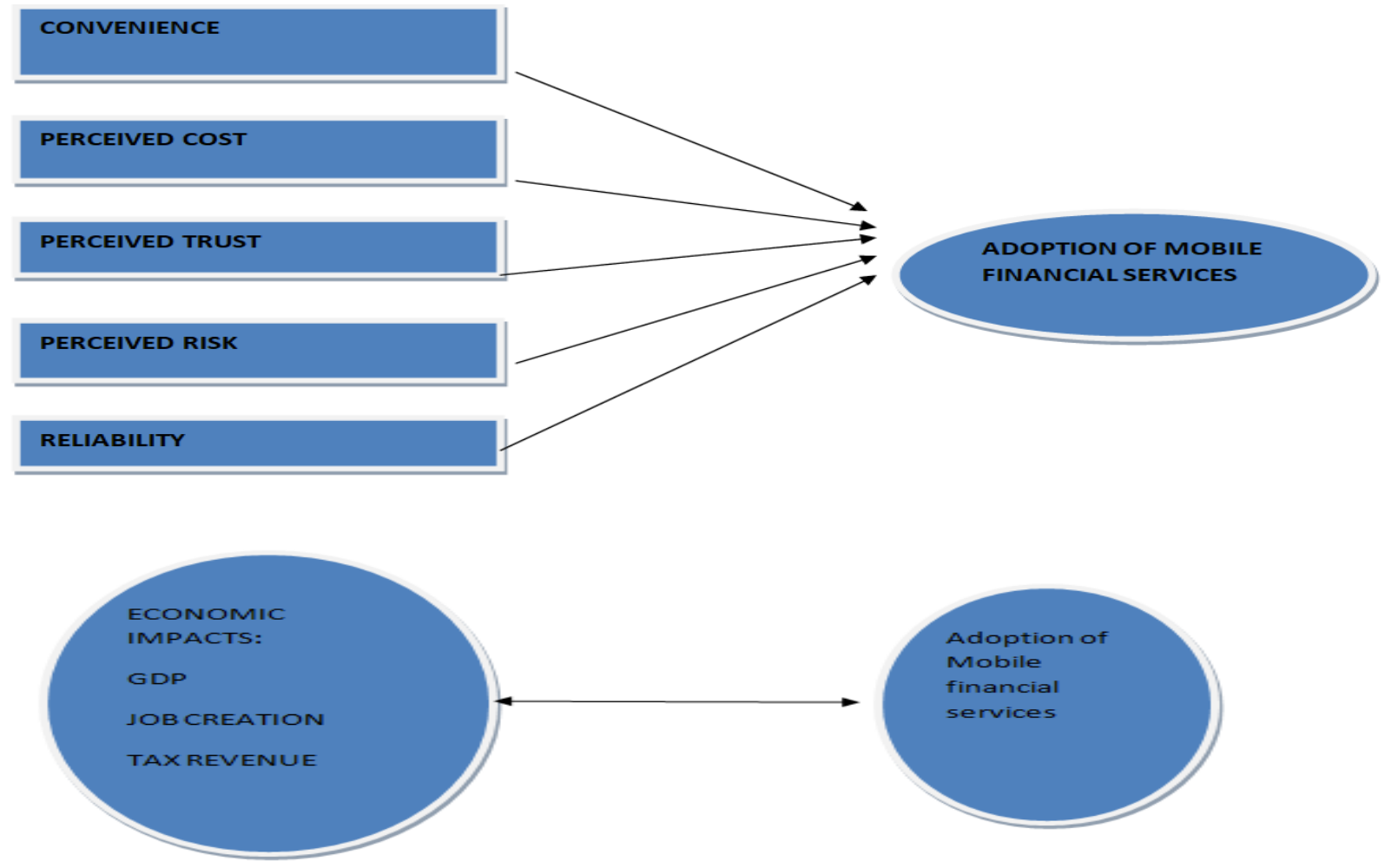

\section{Data Collection}

Data will be collected using an automated questionnaire that was provided to respondents who have access to mobile financial services for initial data collection. A closed-ended questionnaire was used, respondents were asked to give their views on the statement examining the structure at five point Likert scale, with 1 indicating strong disagree, 2 indicating disagree, 3 equal to neutral, 4 equal to agree and 5 equal to strongly agree. Mobile money makers was the target market for the study with a sample size 250 , depending on the rule of thumb that the rate of change in size should be more than 200 (Brown, 2006). Respondents were selected by using a purposive sampling technique. This process was used to get responders with mobile phones and subscribers who use mobile money services. This study uses five independent concepts, namely: convenience (perceived ease of use, usefulness), risk factors, perceived trust, costs and reliability 
to measure factors affecting the acceptance of mobile financial services. For the purpose of the secondary data collection, the data will be analyzed by "The economic and social impact of mobile services (analysis of Pakistan, India, Bangladesh, Serbia and Malaysia) by the relevant authorities Boston (BCG) April 2011"

\section{Research Techniques}

\section{Regression Model}

The linear multiple regression line has been identified as follows:

$$
\mathrm{AMF}=\alpha 1+\beta 1 \mathrm{PR}+\beta 2 \mathrm{~T}+\beta 3 \mathrm{C}+\beta 4 \mathrm{PC}+\beta 5 \mathrm{R}
$$

$\mathrm{AMF}=$ Adoption of Mobile Financial service

$\mathrm{PR}=$ Perceived Risk

$\mathrm{T}=$ Trust

$\mathrm{C}=$ Convenience

$\mathrm{PC}=$ Perceived cost

$\mathrm{R}=$ Reliability

$\alpha 1$ acceptance of mobile financial services without change of risk, trust, accessibility, cost and reliability.

$\beta 1=$ Partial changes in the acceptance of mobile banking services as a result of a change in the perception of risk while other factors persist.

$\beta 2=$ The partial change in the adoption of mobile financial services as a result of one unit change in the Trust variable when all other variables remain constant.

$\beta 3=$ The partial change in the uptake of mobile financial services as a result of one unit change in the Convenience variable while other things remain constant.

$\beta 4==$ A partial acceleration in the uptake of mobile financial services as a result of a one-unit change in the Perceived cost variable while other factors remain constant.

$\beta 5=$ The partial change in mobile financial service uptake as a result of one unit change in the Reliability variable while other things remain constant

\section{Correlation}

The correlation method is used to determine the strength of the relationship between the two data sets. Algorithms provide ratings from -1 to 1 , while 1 indicates the best association. Significant negative association was demonstrated by the value of -1 . Zero results indicate no association.

\section{Reliability Testing (Pilot Testing)}

Case Processing Summary
\begin{tabular}{|ll|r|r|}
\hline & $\mathrm{N}$ & \multicolumn{1}{c|}{$\%$} \\
\hline \multirow{4}{*}{ Cases } & Valid & 250 & 100.0 \\
& Excluded $^{\mathrm{a}}$ & 0 & .0 \\
& Total & 250 & 100.0 \\
\hline
\end{tabular}

a. List wise deletion based on all variables in the procedure. 
Reliability Statistics

\begin{tabular}{|r|r|}
\hline Cronbach's Alpha & N of Items \\
\hline .957 & 78 \\
\hline
\end{tabular}

The Cronbach alpha was used to evaluate the internal consistency of the variable (Cronbach, 1951). For this reason, an experiment was conducted to determine the consistency of the variables. The results revealed that all the variables produced were reliable, with an alpha rate of more than 0.70 , or 0.957, as suggested by Nunnally and Bernstein (1994).

\section{Results of Factors Affecting the Adoption of Mobile Financial Services Correlation}

\begin{tabular}{|c|c|c|c|c|c|c|c|}
\hline \multicolumn{8}{|c|}{ Correlations } \\
\hline & & $\begin{array}{l}\text { MOBILEFINA } \\
\text { NCIALSERVI } \\
\text { CEADOPTION }\end{array}$ & $\begin{array}{l}\text { PERCEIVEDT } \\
\text { RUST } \\
\end{array}$ & $\begin{array}{l}\text { CONVENIEN } \\
\text { CE }\end{array}$ & $\begin{array}{c}\text { PERCEIVEDR } \\
\text { ISK } \\
\end{array}$ & RELIABILITY & $\begin{array}{l}\text { PERCEIVEDC } \\
\text { OST }\end{array}$ \\
\hline \multirow{3}{*}{$\begin{array}{l}\text { MOBILEFINANCIALSERVI } \\
\text { CEADOPTION }\end{array}$} & Pearson Correlation & 1 & $.701^{\prime \prime \prime}$ & $.680^{\prime \prime \prime}$ & $-.142^{\top}$ & $.569^{\prime \prime \prime}$ & .055 \\
\hline & Sig. (2-tailed) & & .000 & .000 & .025 & .000 & .387 \\
\hline & $\mathrm{N}$ & 249 & 249 & 249 & 249 & 249 & 249 \\
\hline \multirow[t]{3}{*}{ PERCEIVEDTRUST } & Pearson Correlation & $.701^{\mathrm{m}}$ & 1 & $.684^{\mathrm{m}}$ & -.091 & $.627^{\mathrm{m}}$ & .038 \\
\hline & Sig. (2-tailed) & .000 & & .000 & .150 & .000 & .554 \\
\hline & $\mathrm{N}$ & 249 & 249 & 249 & 249 & 249 & 249 \\
\hline \multirow[t]{3}{*}{ CONVENIENCE } & Pearson Correlation & $.680^{\mathrm{m}}$ & $.684^{\prime \prime}$ & 1 & -.021 & $.666^{\prime \prime}$ & .087 \\
\hline & Sig. (2-tailed) & .000 & .000 & & .745 & .000 & .173 \\
\hline & $\mathrm{N}$ & 249 & 249 & 249 & 249 & 249 & 249 \\
\hline \multirow[t]{3}{*}{ PERCEIVEDRISK } & Pearson Correlation & $-.142^{\prime \prime}$ & -.091 & -.021 & 1 & -.018 & $.389^{11}$ \\
\hline & Sig. (2-tailed) & .025 & .150 & .745 & & .778 & .000 \\
\hline & $\mathrm{N}$ & 249 & 249 & 249 & 249 & 249 & 249 \\
\hline \multirow[t]{3}{*}{ RELIABILITY } & Pearson Correlation & $.569^{\mathrm{m}}$ & $.627^{\mathrm{m}}$ & $.666^{m}$ & -.018 & 1 & .078 \\
\hline & Sig. (2-tailed) & .000 & .000 & .000 & .778 & & .222 \\
\hline & $\mathrm{N}$ & 249 & 249 & 249 & 249 & 249 & 249 \\
\hline \multirow[t]{3}{*}{ PERCEIVEDCOST } & Pearson Correlation & .055 & .038 & .087 & $.389^{\mathrm{m}}$ & .078 & 1 \\
\hline & Sig. (2-tailed) & .387 & .554 & .173 & .000 & .222 & \\
\hline & $\mathrm{N}$ & 249 & 249 & 249 & 249 & 249 & 249 \\
\hline
\end{tabular}

**. Correlation is significant at the 0.01 level (2-tailed).

*. Correlation is significant at the 0.05 level (2-tailed).

The correlation between the variables was between $\mathrm{r}-0.018$ and $\mathrm{r} 0.0684$. The strongest correlation between predictor variables was found between trustworthiness and accessibility as convenience $(r=0.684)$ indicating strong correlation between variables. Results showed that trustworthiness had a positive correlation with convenience $(\mathrm{r}=0.684$ and $\mathrm{p}<0.01)$ and reliability $(r=0.627$ and $\mathrm{p}<0.01)$. Perceived risk has a significant relationship with only cost as independent variable. The significant values of the correlation between predictor and predicted variables ranged from $r=-0.142$ to $r=0.701$. The results shown in Table 2 show that trustworthiness and accessibility had a strong and significant relationship with the adoption of mobile financial services with $\mathrm{r} 0.701$ and 0.680 at a significant $\mathrm{p}<0.01$ higher than the other independent variables. Reliability also showed a positive correlation with the acceptance of mobile money services at $\mathrm{p}<0.01$. The perceived risk showed a significant negative association with adoption at the $\mathrm{p}<0.05$ level. It was revealed that perceived cost has insignificant influence on the adoption of mobile financial services. 


\section{Regression Analysis (Hypothesis Testing)}

\begin{tabular}{|l|r|r|r|r|}
\hline Model & \multicolumn{1}{|c|}{ R } & R Square & $\begin{array}{c}\text { Adjusted R } \\
\text { Square }\end{array}$ & $\begin{array}{c}\text { Std. Error of the } \\
\text { Estimate }\end{array}$ \\
\hline 1 & $.762^{\mathrm{a}}$ & .581 & .573 & .44917 \\
\hline
\end{tabular}

a. Predictors: (Constant), PERCEIVEDCOST, PERCEIVEDTRUST,

PERCEIVEDRISK, RELIABILITY, CONVENIENCE

$\mathrm{R}$ Square gives a record of the measure of changeability in the predicted variable represented by the predictor variable (Bordens \& Abbott, 2011). So for this situation the above table shows that the worth of $\mathrm{R}$ is 0.762 which is illustrative of the relationship esteem between explanatory and response variable. The above model shows that value of $\mathrm{R} 2$ is 0.581 which shows variability of predictor variable on predicted variable. 0.573 Adjusted R square and St. Deviation Error of the Estimate $=0.44917$ fluctuation of forecast. The correlation value is positive and depicts a good strength of relationship between the dependent and independent variables. The $\mathrm{R}$ Square value is 0.581 which is explaining that diversified results are $41.1 \%$ of variation in dependant variable which is adoption of mobile financial services. It means that $58.1 \%$ of variability shows how the current factors like perceived risk, perceived trust are affecting adoption of mobile financial services and whether it is dependent on other factors not given in this study but they have impact on its adoption.

ANOVA

\begin{tabular}{|rl|r|r|r|r|r|}
\hline \multicolumn{1}{|c|}{} & Sum of Squares & Df & Mean Square & \multicolumn{1}{c|}{ F } & \multicolumn{1}{c|}{ Sig. } \\
\hline & Regression & 68.036 & 5 & 13.607 & 67.445 & $.000^{\mathrm{b}}$ \\
\multirow{2}{*}{1} & Residual & 49.026 & 243 & .202 & & \\
& Total & 117.062 & 248 & & & \\
\hline
\end{tabular}

a. Dependent Variable: MOBILEFINANCIALSERVICEADOPTION

b. Predictors: (Constant), PERCEIVEDCOST, PERCEIVEDTRUST, PERCEIVEDRISK,

RELIABILITY, CONVENIENCE

Table ANOVA test shows the level of significance and F-Status value. The results of this test show that factors like perceived risk, perceived cost, reliability etc. are significantly contributes towards the adoption of mobile financial services that is $(\mathrm{F}=67.445 \& \mathrm{P}=0.000)$ which also means that overall regression model is showing a good model fit.

\begin{tabular}{|c|c|c|c|c|c|c|}
\hline \multicolumn{7}{|c|}{ Coefficients $^{\text {a }}$} \\
\hline \multirow{2}{*}{\multicolumn{2}{|c|}{ Model }} & \multicolumn{2}{|c|}{ Unstandardized Coefficients } & \multirow{2}{*}{$\begin{array}{c}\text { Standardized } \\
\text { Coefficients } \\
\text { Beta }\end{array}$} & \multirow[t]{2}{*}{$\mathrm{T}$} & \multirow[t]{2}{*}{ Sig. } \\
\hline & & $\mathrm{B}$ & Std. Error & & & \\
\hline \multirow[t]{4}{*}{1} & (Constant) & .815 & .227 & & 3.585 & .000 \\
\hline & PERCEIVEDTRUST & .380 & .057 & .401 & 6.639 & .000 \\
\hline & CONVENIENCE & .351 & .064 & .344 & 5.488 & .000 \\
\hline & PERCEIVEDRISK & -.124 & .049 & -.115 & -2.541 & .012 \\
\hline
\end{tabular}




\begin{tabular}{|l|l|l|l|l|l|l|}
\hline & RELIABILITY & .083 & .059 & .083 & 1.407 & .161 \\
\cline { 2 - 7 } & PERCEIVEDCOST & .043 & .040 & .049 & 1.070 & .286 \\
\hline
\end{tabular}

\section{Perceived Trust}

The idea of trustworthiness hypothesis proposes that this independent variable can altogether affect the uptake of mobile money, the result of this analysis also reveal the same thing (â $=$ $0.380, \mathrm{p}=0.000$ ). The results are correspondent with the previous researches that show trustworthiness has beneficial impaction on the reception of mobile money services (Dass \& Pal, 2011b; Chitungo \& Munongo, 2013; Marumbwa \& Mutsikiwa, 2013).

\section{Convenience}

The regression analysis found that perceived usefulness and perceived ease of use have a significant influence on mobile financial service uptake at $\mathrm{p} 0.01$ significance level with $\hat{a}=$ 0.351. These findings support the hypothesis that convenience has a major beneficial impact on mobile financial service adoption. The null hypothesis that convenience has no effect can be rejected because the p-value is less than 0.01. Discoveries are harmonious with Davis' (1989) idea of Technology Acceptance Model (TAM), which depends with the understanding that convenience is the prime factor in influencing new innovation acknowledgment. Different researhers, including Chitungo and Munongo (2013) in Zimbabwe, Lule (2008) in Kenya, Marumbwa and Mutsikiwa (2013) in Zimbabwe, and Dahlberg, Mallat, and örni (2004) also found that convenience was significant in evaluating clients' reception behavior in new technology and testing it with different factors in contrast with Davis' first reception innovation model (1989).

\section{Reliability}

With $\mathrm{a}=0.083, \mathrm{p}>0.01$, the discoveries of this review demonstrated that reliability essentially affected the take-up of mobile money services. It follows that the utilization of a biometric finger impression scanner can't be a solid and safe strategy of making installments or moving cash through digital financial services. The discoveries negate past research, which found that Buckley and Nurse (2019) seem to suggest that unique mark checking (bio metric) is a broadly utilized verification strategy in mobile banking.

\section{Perceived Risk}

The risk as predicted variable contrarily affected the reception of digital financial services ( $\hat{a}=$ $00.124, p=0.012<0.05$ ), as per the hypothesis. Different researches on risk factor show that it has detrimental effect on the uptake of mobile money services (Marumbwa \& Mutsikiwa, 2013; Dass \& Pal, 2011a; Dahlberg, Mallat, \& örni, 2004) support the legitimacy of this review.

\section{Perceived Cost}

The past discoveries demonstrated that cost had insignificant effect on the reception of digital financial services at the $\mathrm{P}>0.01$ significance level with $\hat{a}=0.043$. Other examination (Tobbin \& Kuwornu, 2011; Marumbwa \& Mutsikiwa, 2013; Dahlberg, Mallat, \& örni, 2004; Dass \& Pal, 2011b) uncovered that cost actually affect this predicted variable. 
DATA ANALYSIS OF SECONDARY DATA

\section{Economic Impact of Mobile Financial Services}

The Boston Advisory Group (BCG) examines the impact of mobile money in emerging economies, particularly how having access to bank accounts and credits will change the way people live, work and develop over the years. To guide this study, the forecast from BCG was used to analyze what the picture would look like by 2020. Based on BCG forecast, mobile banking activity could reduce financial exclusion by $5-20 \%$ by 2020 .

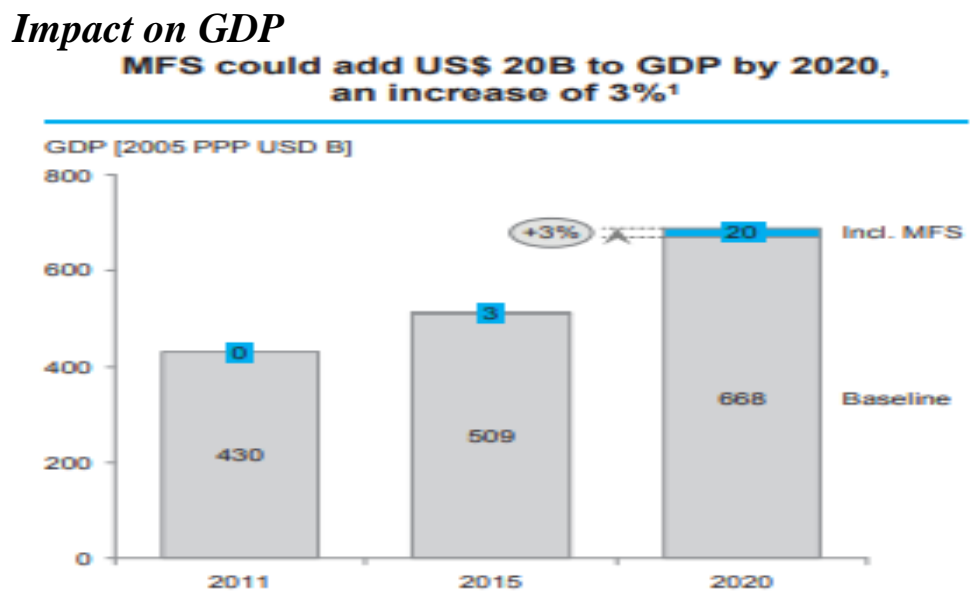

Figure 1. Impact on GDP (Saskatoon, 2018)

There is good evidence that increased investment contributes to GDP. As entrepreneurs with a good business idea get loans, the economy grows and creates jobs. A productive society means many new businesses and new jobs. With mobile money services, by adopting services, Pakistan's GDP could grow by $\$ 20$ billion, or $3 \%$ by 2020 . In addition, there is a kind of accounting benefit of saving money in the banking system, as this would promote the creation of other credits and investments.

\section{New job creation}

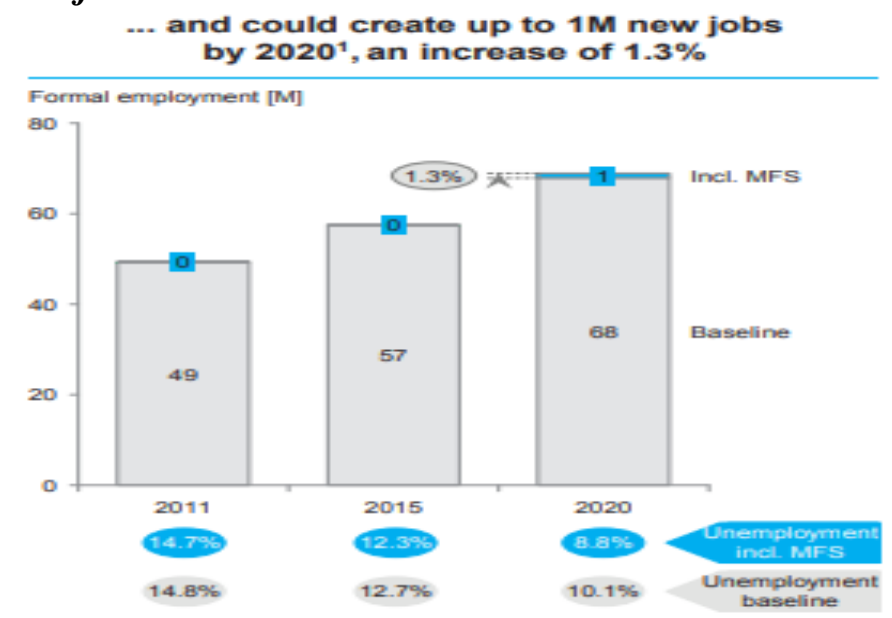

Figure 2. New Job Creation (Saskatoon, 2018) 
By 2020, if MFS adoption increases by 20\%, 600,000 new businesses could be created, creating 1 million new jobs, an increase of $1.3 \%$. That is equivalent to new jobs for 1 out of every 10 Pakistanis currently unemployed.

\section{Tax Revenue Growth}

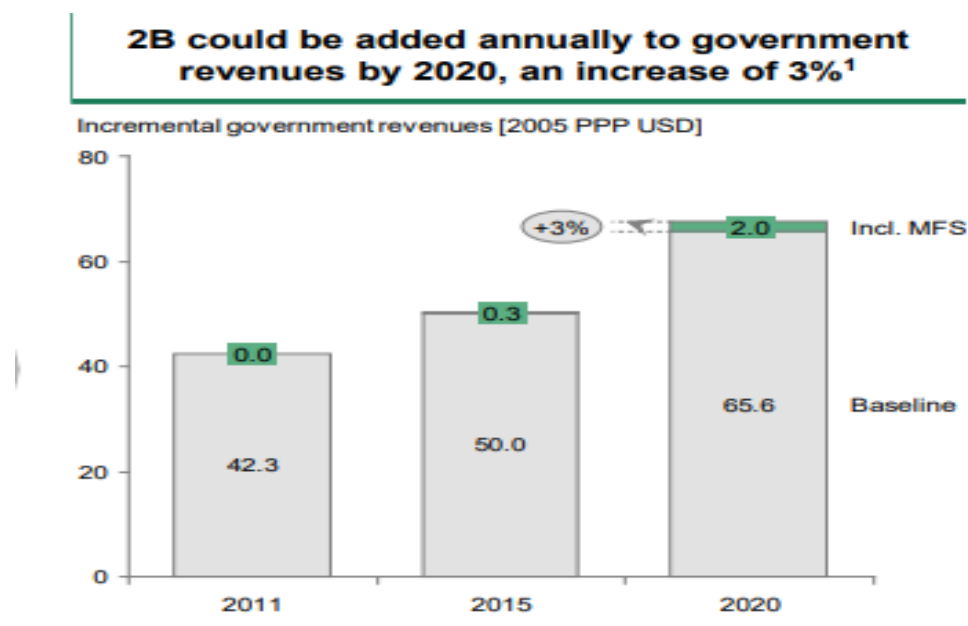

Figure 3. Tax Revenue Growth (Boston, 2011)

The benefits of economic growth stimulated by MFS would increase in tax revenue. Corporate taxes could rise due to the creation of new businesses along the MFS value chain, increasing profits in existing businesses through savings from MFS, and expanding the business made possible by MFS. This growth in business creation could create new jobs, which means higher taxes and income for employees. MFS could add \$ 2 billion annually to Pakistan's government budget by 2020, an increase of $3 \%$.

\section{Discussion of the Results}

On the basis of hypothesis the variables were tested, results of variables like perceived trust, convenience and perceived risk found consistent with earlier studies and other variables like reliability and perceived cost found to have no significant impact on the adoption of mobile financial services as their $\mathrm{p}$ value is greater than 0.05. Similarly data related to economic impact of mobile financial services is also consistent with earlier studies indicating the acceptance of alternative hypothesis.

\section{SCOPE FOR FUTURE RESEARCH}

Social factors such as race, age, gender and culture in the acceptance of mobile banking services have not been studied. According to Lee (2009), the cognitive propensity of individuals to risk varies between cultures, and various demographic characteristics have interrelationships that may influence mobile financial services uptake. This implies that cultural differences may influence client adoption of mobile banking. Again, because the majority of participants were from Karachi, this poll was restricted to adults aged 18 to 30. Including people of diverse ages from both the city and the villages may result in more accurate results. Nonetheless, the risk and 
trust issues demand a more in-depth examination in order to popularise mobile banking throughout the country. Because secondary data on the economic impact of mobile financial services was predictive, self-collected/primary data should be employed in future studies to make the results more precise.

\section{CONCLUSION}

This study was successful in identifying the factors influencing the use of mobile banking in Pakistan. According to the conclusions of this study, perceived risks, trust, and convenience are the factors impacting mobile users' behavioral intention to use mobile financial services in Pakistan. As a result of this research, banks, service providers, and software developers now have more knowledge and information to improve consumers' willingness to use mobile financial services in the future. To summarise, MFS has a lot of potential, but it also has significant limitations. . More than 2.5 billion people in developing countries are impoverished, but many have mobile phones and have formed partnerships with telecommunications corporations. MFS has the potential to be the most powerful economic growth weapon for all of the countries especially for Pakistan. A variety of factors must be developed in order for this potential to be realised. Finally, as the MFS ecosystem evolves, regulators must provide a welcoming climate that minimises risk while allowing for flexibility and innovation.

\section{REFERENCES}

Andrianaivo, M., \& Kpodar, K. (2012). Mobile phones, financial inclusion, and growth. Review of Economics and Institutions, 3(2), 1-30.

Amin, H., Baba, R. \& Mohammed, M. Z. (2007). An Analysis of Mobile Banking Acceptance by Malaysian Customers, Sunway Academic Journal, 1-12.

Aboelmaged, M.G. \& Gebba, T.R. (2013). Mobile Banking Adoption: An Examination of Technology Acceptance Model and Theory of Planned Behavior. International Journal of Business Research and Development, 35-50.

Bångens, D.L. \& Söderberg, B. (2008). Mobile Baking- Financial Service for the Unbanked. Stockholm: The Swedish Program for ICT in Developing Regions, SPIDER.

Bångens, L., \& Söderberg, B. (2011). Mobile Money Transfers and usage among micro-and small businesses in Tanzania. Retrieved from https://www.gsma.com/mobilefordevelopment/wpcontent/uploads/2012/06/sme_and_m mt_final_draft.pdf

Bostan, J. (2011). The Socio-Economic Impact of Mobile Financial Services. Management Science, 51(April), 741-755.

Bhattacherjee, A. (2002). Individual trust in online firms: Scale development and initial test, Journal of Management Information Systems, 19(1), 211-241.

Bordens, K.S. \& Abbott, B.B. (2011). Research Design and Methods: A Process Approach. 8th ed. New York, USA: McGraw-Hill. 
Buckley, O. \& Nurse, J. (2019). The language of biometrics: Analysing public perceptions, Journal of Information Security and Applications, 47, 112-119.

Cronbach, L. J. (1951). Coefficient alpha and the internal structure of tests. Psychometrika, 16, 297-334.

Chale, P., \& Mbamba, U. (2015). The Role of Mobile Money Services on Growth of Small and Medium Enterprises in Tanzania: Evidence from Kinondoni in Dar Es Salaam Rigion. Business Management Review, 17(1), 81-96.

Chitungo, S.K., \& Munongo, S. (2013). Extending the Technology Acceptance Model to Mobile Banking Adoption in Rural Zimbabwe. Journal of Business Administration and Education, 3(1), 51-79.

Caskey, J. P. (2002). Bringing Unbanked Households into the Banking System. A Capital Xchange Journal. The Brookings Institution Center on Urban and Metropolitan Policy, Harvard University Joint Center for Housing Studies.

Chala, A., Aparna., D, Goland, T., Gonzalez, M. J., Morduch, J., \& Schiff, R. (2009). Half the world is unbanked. Financial Access Initiative (FAI) Framing Note, October 2009.

Dass, R., \& Pal, S. (2011a). A Meta Analysis on Adoption of Mobile Financial Services. Ahmedabad, India: Indian Institute of Management (IIMA).

Dass, R., \& Pal, S. (2011b). Exploring the Factors Affecting the Adoption of Mobile Financial Services Among The Rural Under-Banked. Ahmedabad: Indian Institute of Management Ahmedabad.

Davis, F. D. (1989). Perceived Usefulness, Perceived Ease of Use, and User Acceptance of Information Technology. Management Information Systems Research Center, 13(3), 319-40.

Donner J., \& Tellez, C.A. (2008). Mobile banking and economic development: linking adoption, impact and use. Asian Journal of Communication 18(4), 318-322.

Dahlberg, T., Mallat, N., \& Öörni, A. (2004). Trust Enhanced Technology Acceptance Model Consumer Acceptance of Mobile Payment Solution. Retrieved from http://citeseerx.ist.psu.edu/viewdoc/download?doi=10.1.1.200.7189\&rep=rep1\&type=pd f

Horne, D., \& Nickerson, D. (2013). Understanding the Drivers of Mobile Payment Adoption: Comparing Kenya and Tanzania. Gx Intelligence.

Islam, K. M. A., \& Salma, U. (2016). Mobile Banking Operations and Banking Facilities to Rural People in Bangladesh. International Journal of Finance and Banking Research, 2(4), 147. 
Johnston, D., \& Murdoch, J. (2008). World Bank Economic Review, 22(3), 517-553.

Lule, I. (2008). Application of Techology Acceptance Model in mobile Banking adoption in Kenya. Nairobi, Kenya: University of Nairobi.

Li, L. (2010). A critical review of technology Acceptance of Literature. Los Angeles, USA: Grambling State University.

Lee, M.C. (2009). Factors influencing the adoption of internet banking: An integration of TAM and TPB with perceived risk and perceived benefit. Electronic Commerce Research and Applications, 8(3), 130-41.

Masinge, K. (2010). Factors influencing the adoption of mobile banking services at the Bottom of the Pyramid in South Africa. Pretoria, South Africa: Gordon Institute of Business Science (GIBS), University of Pretoria.

Marumbwa, J., \& Mutsikiwa, M. (2013). An Analysis of the Factors Influencing Consumers' Adoption of Mobile Money Transfer Services (MMTs) in Masvingo Urban, Zimbabwe. British Journal of Economics, Management and Trade, 3(4), 498-512.

Nunnally, J. C., \& Bernstein, I. H. (1994). Psychometric Theory (3rd ed.). New York: McgrawHil

Omwansa, T., Waema, T., \& Lules, I. (2012). Application of Technology Acceptance Model (TAM) in MBanking Adoption in Kenya. International Journal of Computing and ICT Research, IV(1), 31-43.

Pickens, M. (2009). Window on the unbanked: mobile money in the Philippines. CGAP Brief, December.

Porteous, D. (2006). The enabling environment for mobile banking in Africa. Report commissioned for DFID.

Porteous, D., \& Wishart, N. (2006). M-banking: a knowledge map. Washington, DC: infoDev / World Bank. Retrieved from http://www.infodev.org/en/Publication.169.html

Sayid, O., Echchabi, A., \& Aziz, H.A. (2012). Investigating Mobile Money Acceptance in Somalia: An Empirical Study. Pak. J. Commer. Soc. Sci., 6(2), 269-81.

Saskatoon, C. (2018). Shaping our financial future. Group.

Tobbin, P., \& Kuwornu, J.K.M. (2011). Adoption of Mobile Money Transfer Technology: Structural Equation Modeling Approach. European Journal of Business and Management, III(7), 59-78. 
Venkatesh, V., \& Davis, F. D. (2000). A Theoretical Extension of the Technology Acceptance Model: Four Longitudinal Field Studies. Management Science, 46(2), 186-204.

Vodafone. (2007). The transformational potential of m-Transactions. Vodafone Policy Paper Series.

World Bank. (2012). The little data book on financial inclusion 2012. International Bank for Reconstruction and Development/The World Bank.

\section{Copyrights}

Copyright for this article is retained by the author(s), with first publication rights granted to the journal. This is an open-access article distributed under the terms and conditions of the Creative Commons Attribution license (https://creativecommons.org/licenses/by/4.0) 